\title{
Rebuilding After a Pandemic, the Place of Engineering Education in Nation Building
}

\author{
Kehdinga George Fomunyam
}

\begin{abstract}
Engineering education was defined as a field, discipline, practice and profession that has ties with the development, acquisition and the application of technical, scientific and mathematical principles to understand, design, implement and invent materials, machines, structures, systems and processes for specific activities. This typifies that engineering education has the drive to make things better. Engineering education is vital for national development and competitiveness. Issues of health are vital to humans and humans are key elements in nation building. At the termination of the year 2019, series of pneumonia cases were discovered in Wuhan China. The corona virus disease 2019 (COVID-19) is an RNA virus with a crown like appearance when viewed under an electron microscope as a result of the presence of glycoprotein spikes on its envelope. The study looked at the place of engineering education to ensure rebuilding after a pandemic. Findings from the study revealed that engineering is important for nation building and various evidences that supports this were considered in this study. The Impetus of engineering education for rebuilding after the pandemic to contribute to nation building was also considered in the study. The study therefore recommended that effort must be made at leveraging on engineering education because of its import for rebuilding after a pandemic.
\end{abstract}

Keywords: rebuilding, engineering, engineering education, COVID-19, pandemic, nation building.

\section{INTRODUCTION}

According to UNESCO report (2010), engineering education is defined as a field, discipline, practice and profession that has ties with the development, acquisition and the application of technical, scientific and mathematical principles to understand, design, implement and invent materials, machines, structures, systems and processes for specific activities. This typifies that engineering education has the drive to make things better. Engineering education is vital for national development and competitiveness (Luiz et $a l, 2004)$ and its important in of supply of electricity, water, roads, telecommunication, transportation, factories, machineries etc. Thisimplies that engineering education is complex with vast application across various disciplines such as the aerospace, chemical and processes, civil and environmental, medical and bioengineering etc. Engineering is vital for some of the advances seen in biomedicine and various infrastructures around us which has influenced human health globally and also contributed to nation building. Issues of health are vital to humans and humans are key elements in nation building.

Revised Manuscript Received on October 25, 2020.

* Correspondence Author

Dr. Kehdinga George Fomunyam*, Institute for Systems Science, Durban University of Technology, Durban, South Africa.

(C) The Authors. Published by Blue Eyes Intelligence Engineering and Sciences Publication (BEIESP). This is an open access article under the CC BY-NC-ND license (http://creativecommons.org/licenses/by-nc-nd/4.0/)
At the termination of the year 2019, series of pneumonia cases were discovered in Wuhan China (Lu, H.; Stratton, C.W.; Tang, Y.W., 2020). Some weeks later in January 2020, deep sequencing from the lower respiratory tract samples revealed that a novel virus with severe acute respiratory syndrome coronavirus 2 (SARS-CoV-2) was the causative agent for the pneumonia cases previously discovered (Huang, C et al, 2020). The corona virus disease 2019 (COVID-19) is an RNA virus with a crown like appearance when viewed under an electron microscope as a result of the presence of glycoprotein spikes on its envelope (Perlman, S.; Netland, J., 2009). The emergence of the novel coronavirus (COVID-19) brought about various disruption to the social, physical, economic, and educational sphere of human endeavor. This resulted in various consequences globally which necessitates the impetus to rebuild going forward from the pandemic. As a result of the consequences of the pandemic, it is necessary to ensure that nations are rebuilt leveraging on engineering education. This study will therefore take a look at the place of engineering education to ensure rebuilding after a pandemic. The study will also take a look at some peculiarities about the pandemic and the need to rebuild after.

\section{METHODOLOGY}

This study is a theoretical discourse which seeks to shed light on rebuilding after a pandemic and the place of engineering in nation building. The study relied on evidences from relevant literature to support the arguments made in this study.

Understanding the place of engineering education in nation building

Some events happening globally has resulted in differences between nations of the world. Some of these events include globalization and westernization which has resulted to colonization of developing countries, brain drain, and language adoption which characterized the cultural hegemony of developed nations. To ensure better conditions and to overcome the failure of leadership and promote good governance, nation building came to the fore. Nation building is an attempt by newly independent nations to reshape territories that had been delineated by colonial masters, powers or empire without recourse to ethnic, religious or other boundaries (Deutsch KW, William JF (1963)). It can also be the process of establishing civility and governmental roles in nations that are just emerging from periods of war or other disorder (Pan E (2005)). It's an exchange between developed and less developed country to overcome state failures and ensure survival of states.

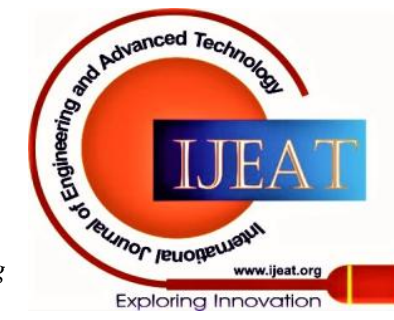

and Sciences Publication

(c) Copyright: All rights reserved. 
To suit the context of this study, nation building include regional, political, social and economic processes that are aimed at national development. It seeks to connect the structures of a country (political, economic, infrastructure, cultural, educational etc.) into a unified system. It is an avalanche of programmes and policies put in place to ensure that the state does not fail (CABE,2010). Engineering education has vital roles to play in national development which will be considered. Engineering education as a discipline has been pivotal to nation building since civilization began. From a cursory look at history, humans have evolved from simple being to more complex ones after gaining a mastery of their environment. as civilization began, humans were challenged by the need to survive and they tried to explore different means to achieve this. With the exploration came mastery of the environment and development of tools that could help them facilitate this. The most basic human needs in life according to Maslow (1943) which are food, shelter and clothing was essential to them and they explored the environment to achieve this. It is important to note that human survival is predicated on the availability of these basic needs and to achieve that, they depended on the environment. The environment consists of all the factors that surrounds humans and as humans evolved, they explored the environment using their ingenuity to create simple tools. As time progressed and humans gained more mastery of the environment, more complex tools were developed which kick started engineering processes in the world. This has assumed a greater pace and volume now as there are varieties of tools, machineries, infrastructures that have been developed as a result of the knowledge of engineering education and its application. This kickstarted the contribution of engineering education to nation building. Evidences of these are seen in history such as pyramids of Egypt (2500BC), King Goujian`s Bronze Sword (500BC), Dujiangyan water engineering project (300BC), and the great walls of China (206, BC). These all contributed to the growth and development of nations. This is in line with the findings of the Royal Academy of Engineering (RAE) which revealed that engineering in Sub-Saharan Africa has the drive to contribute to economic and social development in any country (Matthews et al, 2012). As time progressed and civilization improved, engineering education had major contribution to nation building and this was manifested in reputable changes made during the 21st century. The trio of education, research and innovation brought about the expansion of engineering education in the $21^{\text {st }}$ century which culminated in the creation of various infrastructure that contributed to nation building. Some of these infrastructures include good roads, airports, ships, high-rise buildings, elevators, advances in medicine etc. With these infrastructures in place, the conduct of events was changed and it had influence on all spheres of human endeavor which include the physical, social, cultural, educational, economic etc. The tempo of life increased and it brought about tremendous changes in nation building and national development. Production is a major part of nation building and it must be encouraged and by the apparatus of engineering education, it has been influenced. From the creation of simple tools to the various complex machineries that are now in place now, the production scenery has been influenced positively. As the world transitioned from one epoch to another chronicled in the industrial revolutions, series of changes have occurred that has the capacity to influence production and consequentially nation building. The movement from the Fordist-era to the highly industrialized era also has within its purview the import of engineering education as a major player in production which consequentially influences nation building. It is important to note that civilization is gradual and different nations of the world have embraced it as a result of some factors. Some of these factors include education, nearness to civilization, economic stability, absence of wars and natural disasters, government policies etc. This difference in terms of civilization is seen in the divide between countries of the Global South and the Global North. One characterized by a vast development, highly developed economy, good infrastructure, high literacy, dependence on secondary and tertiary production etc. while the other is characterized by dependence on primary production, poor development, poor infrastructures, widespread poverty, massive illiteracy, technological backwardness etc. As societies become civilized as a result of the factors mentioned above, the differences between countries of the world came to the limelight. Adopting engineering education as nations became civilized and progressed has been a major contributor to nation building. The pace at which engineering is leveraged on and adopted in societies of the world has encouraged their capacity for nation building. With engineering education influencing the entire sphere of human life, commerce has been affected positively and its conduct shaped. The means and exchange in commerce in time past was crude and it does not properly reflect standard measures and value for money. Hence, as time evolved and simple machines were created, the conduct of commerce assumed and overhaul and various standard measurements became commonplace while legal tender (a means of exchange acceptable legally in a location) was also introduced. This ensured that commercial activities take a new turn with the real exchange and measures assuming a facelift. This in the long run contributed to nation building by ensuring that elements pivotal for commerce to thrive are put in place and this has the capacity to prevent chaos and disruption in the society hence encouraging nation building across the countries of the world. To ensure that the nation does not fail which is an element of nation building, some things must be put in place which include transportation. The means of transportation in time past was crude and less functional which also come with lots of rigors. But as civilization came, better systems of transportation were produced which include automobiles, aircrafts, ships, cable cars, pipelines etc. All these cannot be possible without the contribution of engineering education. The availability of better transportation system is crucial to nation building and it has helped to facilitate commercialization, production, international exchange and diplomacy, tourism etc.

Published By:

Blue Eyes Intelligence Engineering

and Sciences Publication

(C) Copyriaht: All riahts reserved.

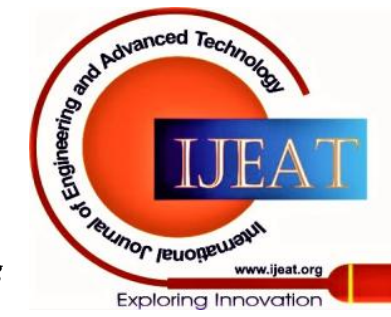


All these are vital to ensuring nation building in the countries of the world. With the advent of the 21st century, there are tremendous progress made in transportation brought about by engineering education and these have in it the major aim of encouraging movement comfortably while also reducing the time constraint. There are now automobiles that can move in quick time and get things done quickly. To encourage nation building, there must be international exchange between the nations of the world and without the apparatus of engineering education, this might be impossible. It is important to note that as a result of environment, location and so many other factors, there are differences among the countries of the world and no single country has all it takes to survive alone without depending on others. Those with the highly developed infrastructures need resources to power the infrastructures while those with the resources need the highly developed nations to buy their resources. Dependency is a major factor in international relations and there has been social exchange, technological exchange, financial exchange, educational exchange etc. and this has the capacity to contribute to nation building but it requires the apparatus of engineering education. Oil from the developing nations are extracted and since they have poor capacity to refine the oil, they depend on developed nations as their major source of sales and the developed nations also helps them in refining their crude oil. This is a dimension by which exchanges take place between developed nations and developing nations and engineering education has major part to play in such exchange.

It is vital to now understand that all attempts at encouraging nation building cannot be possible without the import of engineering education and some of these dimensions has been captured above such as in production, civilization, commerce, transportation etc.

\section{DEMYSTIFYING THE PANDEMIC CONUNDRUM}

The occurrence of pandemic is not new and globally, the last encountered pandemic was the influenza outbreak (H1N1) that occurred in the year 1918-1919 and it has mortality ratios between 50 and 100 million (Johnson \& Mueller,2002 and other consequences such as mental health issues as an aftermath (Young, 2016). This typifies the detrimental nature of pandemic globally and its high decimating power. Mortality is not only the consequence of pandemic, there are also other ones such as mental health and other psychological issues suffered by humans during the aftermath of the pandemic. some of the other psychological issues that occur after pandemic include stigmatization, anxiety and obsessive compulsive disorders, medical mistrust and conspiracy theories, aggression, frustration and post-traumatic stress disorder (Shigemura et al, 2020_etc. These all have damning consequences on human health if appropriate care is not taken. Occurrence of pandemic is such an unfortunate occurrence which affect all aspect of human life including human health and there is a need to rebuild after a pandemic. as a global human disaster, it has various consequences on humans, systems and processes, structures and conducts of events and going forward from that, there are tremendous changes which takes place across the globe.
Coronavirus disease 2019 (COVID-19) which was first discovered in December 2019 is the premier coronavirus $(\mathrm{CoV})$ pandemic of the $21^{\text {st }}$ century. It has been reputed to be the most serious CoV outbreak and as at March 2020 as revealed by WHO (2020a), there has been 266073 cases and 11183 deaths which surpassed the severe acute respiratory syndrome of 2003 with 8906cases and 774 deaths and the middle east respiratory syndrome with 2494 cases and 858 deaths (WHO,2020b: WHO,2020c). These statistics attest to the fact that COVID-19 is more serious in terms of its consequence on morbidity and mortality than the other epidemic suffered in time past. This also reinforces the idea that as humans progress and more is known about diseases, there will be more outbreaks in the future which will come with more grievous consequence and as a result of this, it is essential to prepare for any of such occurrence from happening because of the effect it has on the global community. There are four genera of CoVs and they are (i) $\alpha$ _coronavirus (alphaCoV), (II) $\beta$ _-coronavirus (betaCoV) probably found in bats and rodents, while (III) $\delta_{-}$coronavirus (deltaCoV), and (IV) $\gamma$-coronavirus (gammaCoV) probably found in birds (Perlman, S.; Netland, J., 2009: Lu, R, 2020: Yin, Y, 2018). It has been revealed in research that the virus can be traced to natural and zoonotic origin and the possible scenarios surrounding its origin include natural selection in a host which is an animal before it is being transferred through zoonosis and the other, natural selection in humans after it has been transfer through zoonosis (Lu, R.;,2020:Yin.Y et al, 2018,). This implies that the two major origin of the virus is from natural selection in a host and zoonotic transfer. What makes the disease more serious and dangerous is the fact that clinical features and risk varies highly and each new day, new revelation unfolds on the clinical features of the virus as the virus has the capacity to evolve. From research the clinical symptoms can range from asymptomatic to fatal and both has consequence (Phan,T. 2020). The COVID-19 epidemic was detected in early December in Wuhan which is China`s $7^{\text {th }}$ most populous city which was then carried to an increasing number of nations. As it became exported, the first confirmed case of COVID-19 outside china was diagnosed in Bangkok (Thailand) on $13^{\text {th }}$ January 2020 (WHO,2020d). This transmission assumes a new dimension and on the $2^{\text {nd }}$ of march 2020, 67 territories from mainland china had 8565 confirmed cases with 132 deaths and widespread community transmission in various countries of the world and from the pace of its spread, it was declared by WHO on the $11^{\text {th }}$ of march 2020 as a pandemic (Hsu,2020). Ever since then, the number of confirmed cases has been on an increase as there is no known cure for it and no vaccine has been proven to overcome the menace of COVID-19. Going forward from the spread of COVID-19 and to discourage its spread, major countries of the world announced a lockdown, shut their airspaces and reduced movement so as to curb the spread of the virus. This came with lots of consequences globally as only essential services thrived while other services were put on a standby.

ed By:

Blue Eyes Intelligence Engineering and Sciences Publication (C) Copyright: All rights reserved.

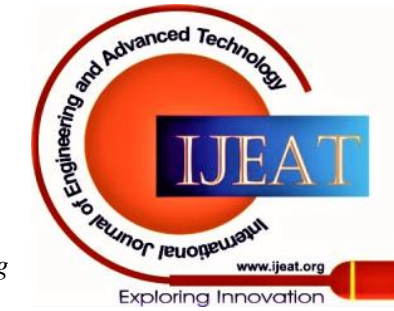


This affected most nations economically and in other dimensions which necessitates the impetus to rebuild after the pandemic.

Impetus of engineering education for rebuilding after the pandemic to contribute to nation building

Rebuilding according to Merriam Webster Dictionary (2020) means to make extensive repairs/changes to or to restore to a previous state. This definition implies that there has been an ideal state before which has been affected by various circumstances which then requires the need to restore to such state. The pandemic has affected the way things were done in time past and the context, conduct and condition in which things are done has been affected hence the need to rebuild. Going forward from the pandemic, existing structures in time past has been affected and this is seen in many dimensions. Lots of businesses have been shut down while others have downsized, there has been reduction in income, collapse of sectors, economic disorder, overhaul in systems and processes. It is important to note that as a result of the lockdown enforced by most countries of the world, it has come with consequences on major means of production and most countries are trying to gradually rebuild from the pandemic. The process of rebuilding is not a sudden disruptive one and it takes time to rebuild while also putting in mind that things might not be the same again. This implies that the nation must forcefully assume the new normal and deal with it while also trying to overcome the scourge of the pandemic. During the lockdown, airspaces were shut which restricted international movement, nonessential activities were stopped which affected human livelihood, some industrial activities were halted which affected nations, citizens and individuals, social and religious activities were disrupted as people could not gather to have fun and do their religious duties, educational activity also was affected as the academic institutions were shut for a while. All these have its own consequences which has been highlighted above and the major thing is to ensure how to recover from all these hence the need to rebuild. Engineering education is vital for nation building and evidences of this has been demonstrated above. Much more than this, it is important for rebuilding after the pandemic. Avenues through which engineering education was helpful in rebuilding and can be helpful will be considered. Technologies are vital in ensuring that systems and nations are rebuilt after the pandemic Going forward from the pandemic, there was the need to develop devices that can help to reduce the menace of the virus and also protect health workers and this forced engineers to boost their learning cycle. A report sponsored by Bae Systems (2020) on Newscientist revealed that the emergence of the pandemic created a sense of urgency to accelerate learning by engineers which helped in boosting the production of personal protective devices and other equipment's that aided the process of rebuilding after the pandemic. also, the need to build hospitals quickly and donating lifesaving equipment's has been the forte of engineering education which has helped the process of rebuilding after the pandemic. As most countries are emerging from the lockdown, it is important to note that the world of work and life has changed and it brought with it immense opportunity to innovate. The essence of engineering education captured in the widespread advances seen in telecommunication has affected the way we live and work and key among this is the need for remote working which seems to be more fascinating lately. A statement by HayaatunSillem, the chief executive of the Royal Academy of Engineering stated that "we are never going back to the rigidity of what working hours and days look like". The new normal will be influenced by advances in engineering education which has affected the way we work and encouraged remote working in major parts of the world. This also has the capacity to improve accessibility and flexibility while also encouraging diversity and inclusion by ensuring that the vulnerable are taken care off by them working remotely. The emergence of video call as a feature of engineering education is a boost for remote working and people across various geographical divides can sit before a screen and communicate without coming close to each other. This has exempted the niceties and preamble done in a meeting, removed the rigors of repeating issues discussed to the guy who came late and it has made meeting more efficient. In order to rebuild, there is the need for core engineering skills which must be leveraged on to encourage nation building. There is now high demand for engineering skills and other skills in artificial intelligence, big data etc. which has the impetus to encourage rebuilding after the pandemic. New challenges require new skillset to deal with them and there is a need for engineers to rise up to this challenge so as to ensure that the nations are rebuilt after this pandemic. There is therefore the need for intensified effort on investment in culture and skills that is needed to rebuild in the new normal. There is a need to deal with moving systems which is the role of engineering education. The emergence of the fourth industrial revolutionand its emerging technologies has influence on engineering education which will consequentially improve the process at rebuilding and nation building after the pandemic. Prototyping, robotics and automation and 3D printing is becoming commonplace today and this can be done remotely to rebuild after the pandemic. robotic process automation (RPA) will take over boring, repetitive tasks and it frees people up to tackle other important and non-automated duties which helps the rebuilding process and also contribute to nation building. With the new normal, efficiency and multitasking will be desirable features which the emergence of technologies in engineering education provides. Rebuilding requires a shift of some portions of work offsite and this can be made possible by virtual events. Virtual events facilitated by discoveries in engineering education has become the norm and it is helpful in rebuilding after the pandemic. With most onsite events cancelled, people relied on these virtual events to keep up. High level digitization globally will ensure that people are more connected and this will ensure that some jobs are carried out virtually without the challenge of being in a place at a time. This can only be made possible by engineering education which will contribute to nation building.

\section{Published By: \\ Blue Eyes Intelligence Engineering}

$$
\begin{aligned}
& \text { and Sciences Publication } \\
& \text { (C) Copyriaht: All rights reserved. }
\end{aligned}
$$

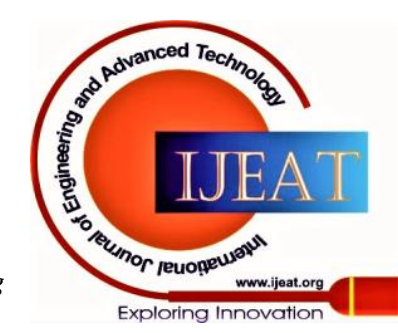


Digital collaboration, 4D and 5D simulation to re-plan projects and re-optimize schedules etc. are pivotal to rebuild which can only be made possible by the technologies emerging in engineering education.

\section{FINDINGS AND DISCUSSION}

It is important to note that the place of engineering education and its multi-versatility cannot be undermined. From the definition by the Royal Academy of Engineering, it captures the essentialities captured in the discipline. It has the potency to create, design, solve, improve process, structures and systems. It is also multi-dimensional having wide application across various fields such as medicine, bioengineering, aeronautical engineering, construction etc. This captures the complexity of engineering education and its impetus to contribute to various fields of endeavor. Findings from this study revealed that engineering is as old as human civilization and it has always been with people over the years. The need for shelter, clothing and food necessitates the drive to apply some engineering principles to overcome this. By gaining mastery of the environment, some engineering principles were deployed such as the use of simple tools to create things. As civilization improved and the earlier men gain more mastery of the environment, they graduated to creating better tools that helped them in their survival and daily activities. This has been the path engineering took from being a simple discipline characterized by creation of crude implements to one highly complex and characterized by various heavy machineries that helps in delivering on its ideals.

Findings from the study also revealed that issues of health are vital to humans and humans are key elements in nation building. Humans make up the nation and any general health condition portends grievous challenges for a nation at large. At the termination of the year 2019, series of pneumonia cases were discovered in Wuhan China. After some weeks in January 2020, deep sequencing from the lower respiratory tract samples revealed that a novel virus with severe acute respiratory syndrome coronavirus 2 (SARS-CoV-2) was the causative agent for the pneumonia cases previously discovered (Huang, C et al, 2020). The corona virus disease 2019 (COVID-19) is an RNA virus characterized with a crown like appearance under an electron microscope as a result of the presence of glycoprotein spikes on its envelope (Perlman, S.; Netland, J., 2009). The emergence of the disease and its spread caused various disruption to all sphere of human endeavor which ranges from social, cultural, academic, political, economic, environmental etc. This therefore necessitated the impetus to rebuild and to also contribute to nation building after the pandemic.

It was also found out that engineering education has much in it for rebuilding after the pandemic to contribute to nation building. Rebuilding according to Merriam Webster Dictionary (2020) means to make extensive repairs/changes to or to restore to a previous state. This definition implies that there has been an ideal state which existed before and has been affected by an external factor and the need to go back to the ideal state which could be achievable by the apparatus of engineering education. The need to develop devices that can help to reduce the menace of the virus and also protect health workers and this forced engineers to boost their learning cycle. Also the various consequences from the pandemic necessitated an overhaul to production processes which can be brought about by changing the existing work pattern through improving structures, automation, remote work and monitoring, development of new skills etc.

\section{V.}

\section{CONCLUSION AND RECOMMENDATION}

The objective of this paper is to provide a basis for rebuilding after the pandemic by leveraging on engineering education while also contributing to nation building. The study therefore recommended that more research is needed on the COVID-19 disease to fully understand its dynamic and effort must be made at leveraging on engineering education because of its import for rebuilding after a pandemic.

\section{REFERENCES}

1. http://www.raeng.org.uk/publications/reports/assessing-the-economicreturns-ofengineering-rese

2. Lu, H.; Stratton, C.W.; Tang, Y.W. Outbreak of pneumonia of unknown etiology in Wuhan, China: The mystery and the miracle. $J$. Med. Virol. 2020, 92, 401-402.

3. Huang, C.; Wang, Y.; Li, Z.; Ren, L.; Zhao, J.; Hu, Y.; Zhang, L.; Fan, G.; Xu, J.; Gu, X.; et al. Clinical features of patients infected with 2019 novel coronavirus in Wuhan, China. Lancet 2020, 395 497-506.

4. Perlman, S.; Netland, J. Coronaviruses post-SARS: Update on replication and pathogenesis. Nat. Rev. Microbiol. 2009, 7, 439-450.

5. UNESCO Report (2010) Engineering: Issues Challenges and Opportunities for Development (accessed on 11/25/2016 8:22 AM).

6. Maslow, A.H. (1943) A theory of human motivation. Psychological review, 50(4), 370-96

7. Matthews, P., Ryan-Collins, L., Wells, J., Sillem, H. and Wright, H. (2012). Engineers for Africa: Identifyingengineering capacity needs in sub-Saharan Africa. Royal Academy of Engineering, Africa-UK Engineering for Development Partnership.

8. Deutsch KW, William JF (1963) Nation building. Atherton Press, New York, USA.

9. Pan E (2005) United Nations: Nation building, council on foreign relations:

10. Backgrounder.

11. Commission for Architecture and the Built Environment (CABE). 2010

12. Young Jm. 2016. The politics of contagion.

13. Johnson NP \& Mueller J. 2002. Updating the accounts: global mortality of the 1918-1920 "Spanish" influenza pandemic. Bulletin of the history of medicine. 105-115

14. Shigemura J, Ursano RJ, Morganstein JC, Kurosawa M \&Benedek DM. 2020. Public responses to the novel 2019 coronavirus (2019 $\mathrm{nCoV}$ ) in Japan: mental health consequences and target populations. Psychiatry Clin Neurosci

15. World Health Organization. 2020. Coronavirus disease (COVID-19) situation report-61. Available: https://www.who.int/docs/defaultsource/coronaviruse/situation-reports/20200321-sitrep-61-covid19.pdf\%0A

16. World Health Organization. 2020b. summary of probable cases with onset of illness from 1 November 2002 to 31 July 2003, 2004 Available: https://www.who.int/csr/sars/country/table2004_04_21/en/

17. World Health Organization. 2020. Middle east respiratory syndrome coronavirus (MERS-CoV). Available: https://www.who.int/emergencies/mers-cov/en/

18. Perlman, S.; Netland, J. Coronaviruses post-SARS: Update on replication and pathogenesis. Nat. Rev. Microbiol. 2009, 7, 439-450.

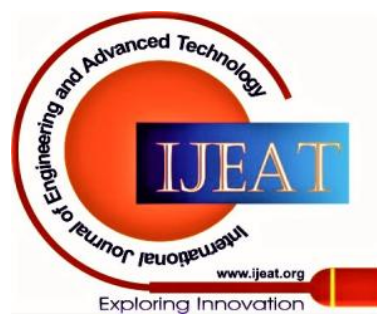


19. Lu, R.; Zhao, X.; Li, J.; Niu, P.; Yang, B.; Wu, H.; Wang, W.; Song, H.; Huang, B.; Zhu, N.; et al. Genomic characterization and epidemiology of 2019 novel coronavirus: Implications for virus origins and receptor binding. Lancet 2020, 395, 565-574.

20. Yin, Y.;Wunderink, R.G. MERS, SARS and other coronaviruses as causes of pneumonia. Respirology2018, 23, 130-137.

21. Lu, R.; Zhao, X.; Li, J.; Niu, P.; Yang, B.; Wu, H.; Wang, W.; Song, H.; Huang, B.; Zhu, N.; et al. Genomic characterization and epidemiology of 2019 novel coronavirus: Implications for virus origins and receptor binding. Lancet 2020, 395, 565-574.

22. Yin, Y.;Wunderink, R.G. MERS, SARS and other coronaviruses as causes of pneumonia. Respirology2018, 23, 130-137.

23. Phan, T. Novel coronavirus: From discovery to clinical diagnostics. Infect. Genet. Evol. 2020, 79.

24. World Health Organization Novel Coronavirus (2019-nCoV), Situation Report 1. 21 January 2020. Available online: https://www.who.int/docs/defaultsource/coronaviruse/situationreports/20200121-sitrep-1-2019-ncov.pdf

25. Hsu, L.Y.; Chia, P.Y.; Lim, J.F. The Novel coronavirus (SARS-CoV2) epidemic. Ann. Acad. Med. Singap. 2020,

26. 49, 1-3.

27. Bae systems. 2020. https://www.newscientist.com/article/2251823engineering-in-a-post-pandemic-world/

\section{AUTHOR PROFILE}

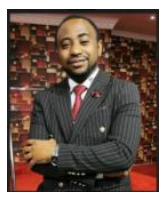

Dr. Kehdinga George Fomunyam, Institute for Systems Science, Durban University of Technology, Durban, South Africa.

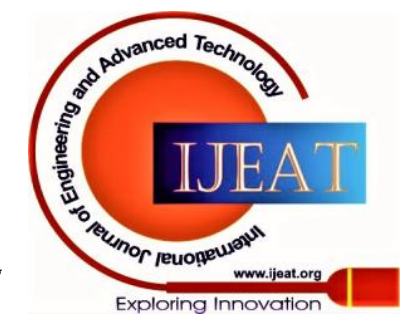

